\title{
EFFECT OF HIGH GRAVITY WORT FERMENTATION PARAMETERS ON BEER FLAVOR PROFILE
}

\author{
Ruslana Kosiv, * , Tetiana Kharandiuk ${ }^{1}$, Lubov Polyuzhyn ${ }^{1}$, Lubov Palianytsia ${ }^{1}$, \\ Natalia Berezovska ${ }^{1}$
}

https:

\begin{abstract}
The effect of main fermentation temperature on a young beer taste has been studied within the range of 282-292 K for high-density wort with the concentration of $14-18 \%$ dry matter. The taste is provided by the content of aromatics - by-products of fermentation: acetaldehyde, vicinal diketones, $n$-propanol, $n$-butanol, $i$ butanol, 2-methyl-butanol, 3-methyl butanol, ethyl acetate and isoamyl acetate.
\end{abstract}

Keywords: beer, flavor profile, high gravity brewing.

\section{Introduction}

In recent years beer industry is rapidly developing in our country despite a slight decrease in beer production. In this regard the intensification of the process is of great attention. The changes in technological regimes aimed at the reduction of process duration, energy consumption, improvement the drink quality, as well as the use of new generation yeast strains make necessary to study the influence of technical and technological innovations on beer flavor [1].

The main properties of beer - taste and aroma - are influenced by a huge number of components. All flavor components act together and create together with aromatic substances a sensory profile of the product. The taste of beer can be divided into three components: taste at the beginning of swallowing, middle taste and aftertaste. Taste at the beginning of swallowing is determined by beer aroma and fullness of taste, "middle" - by a sense of freshness, and aftertaste is mainly determined by the bitterness of the drink. There is no well-defined boundary between these feelings, and theoretically they must be balanced.

Beer contains a large amount of flavor components that are usually present in concentrations below or close to

\footnotetext{
${ }^{1}$ Lviv Polytechnic National University

12 S. Bandery St., 79013 Lviv, Ukraine

kosivruslana@gmail.com

(c) Kosiv R., Kharandiuk T., Polyuzhyn L., Palianytsia L., Berezovska N., 2017
}

the sensitivity threshold. If the concentration of one or more components increases significantly, then there may be flavor defects or off-flavor. This can be detected by tasting. Beer organoleptic control is necessary starting from the early stages of production; the raw materials, young, fully riped and ready beer must be controlled [2].

The basis for taste and aroma evaluation is a regular beer without flaws. Regular beer must have the right balance between bitterness, acidity, sweetness, alcohol content, esters concentration and pleasant hop aroma [3]. This beer also contains a large number of different components in micro-amounts. In addition, it should have sufficient amount of carbon dioxide, which provides beer with relevant foam and pleasant freshness.

All beer components can be divided into four main groups [4]: main, secondary, tertiary and background flavor components. The group of main components includes the substances with concentrations of more than twice exceeding the sensitivity threshold. In a regular beer, without foreign tastes, only ethanol, carbon dioxide and bitter hop substances belong to this group. In the group of secondary components there are substances, the concentrations of which are 1.2 times higher than the sensitivity threshold. Many of the most important beer flavor compounds are in this group. The difference between one and another beer of the same class are mainly determined by variations in the group. Isoamyl acetate, ethyl caprylate, ethyl acetate and amyl alcohols are the most important agents of the second group. The third group of flavoring components includes substances the concentration of which is $0.1-0.5$ below the sensitivity threshold. These components as themselves play a minor role, but together or in a group they are important. The examples of these components are phenylethyl acetate and acetoin. The background components include flavoring substances in concentrations of more than 10 times below the sensitivity threshold. This group includes hundreds of different components, and they form the so-called background taste of beer.

All flavor components in beer act together and they are responsible for sensory quality of the product. 
Ultrahigh concentrations of certain flavor components can provide beer with untypical taste. However the defect may be caused by the absence or very low concentration of important flavor component.

Scientists involved in sensory analysis found convenient to imagine different tastes and aromas in the form of a wheel (Fig. 1). American Society of Brewing Chemists (ASBC), European Brewery Convention (EBC) and the American Association of Brewers agreed terms which can be used to describe the taste and aroma of beer and which may be understandable everywhere. The Flavor Wheel consists of 14 classes. Classes consist of 42 firsttier terms, each term is marked by four numerals [5].

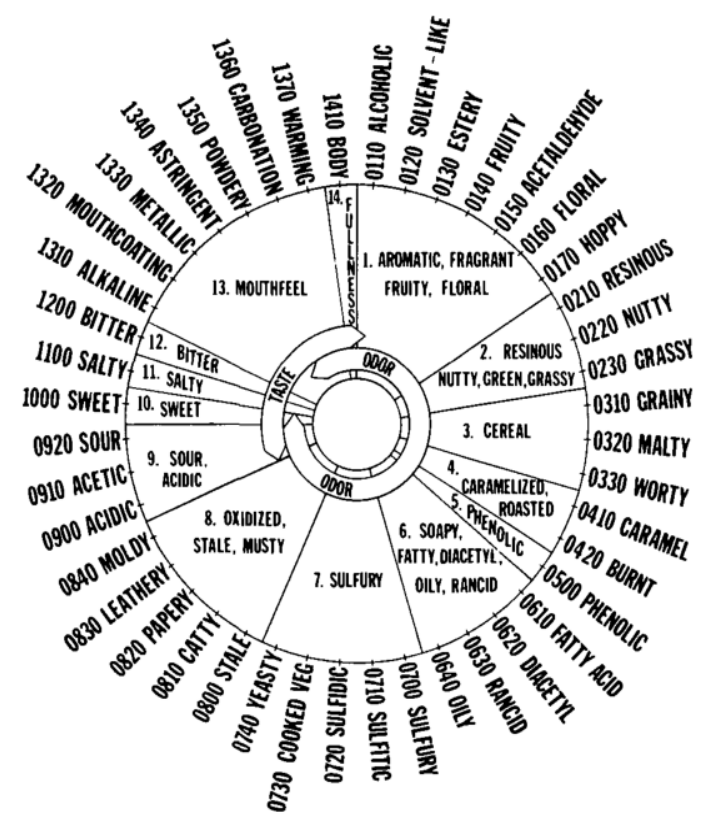

Fig. 1. The Flavor Wheel, showing class terms and first-tier terms [5]

L. Tretiak [6] noticed that various known sensory tests (sensory analysis of beer according to EBC, sensory profile of beer taste and aroma, 25-point sensory scheme, consumer test, double test, duo-trio test, tetra-test) have a mathematical uncertainty and they are described by the feelings of tasters. The most detailed characteristics of taste and aroma is standardized as a terminology system, consisting of 14 classes with detailed decomposition into 122 different characteristics of taste and aroma. However, these characteristics are advertising (not technological) information about flavor properties of beer brand and pursue the goal to obtain organoleptic profiles created by professional tasting commissions. For example, W. Simpson [7] believes that for the "fingerprints" of taste and aroma of conventional light lager beer about 40 taste aromatic descriptors "would be enough".

According to Ref. [6], the only one way to evaluate mathematically the contribution of flavor and aroma of separate substances to the general bouquet of particular brand of beer allowing to simulate any flavor profile is the ratio between substance concentration and its identification threshold. "The identification threshold" means the minimum incentive that can qualitatively describe the nature of feeling [8]. The basis of such approach is a proposal made by M. C. Meilgaard [5] to evaluate the contribution of a substance relative to the concentration exceeding the sensitivity threshold.

L. Tretiak [6] established a correlation between groups of chemicals compounds - supports of definite taste aromatic properties. Thus, bitter flavors (bitter substances of beer, iso- $\alpha$-acids, xanthohumol) are $50.0 \%$ of the total sum; sweet and sugary-sweet flavors (glycerol, diacetyl) $-25.7 \%$; fruity flavors (isopentyl acetate, acetoin, ethyl acetate, methyl acetate, isoamyl acetate, vinyl acetate, isobutyl acetate, acetaldehyde, phenyl acetate, 2-phenyletanol) - $12.4 \%$; sulfur (negative, undesirable) off-flavors (dimethyl sulfide, ethane thiol, sulfur dioxide) $-4.7 \%$; winy, alcohol or fusel off-flavors (isoamyl, methyl, propyl, butyl and isobutyl alcohols) $3.9 \%$, fat and soap (undesirable) off-flavors (caprylic, butyric, lauric and capric acids) $-3.3 \%$.

L.Tretiak [9] proposed the beer classification according to the typical flavor properties taking into account the consumer market segmentation (Table 1).

Table 1

Merchandizing classification according to the typical flavor properties

\begin{tabular}{|l|c|c|c|c|c|}
\hline \multirow{2}{*}{ Supports of beer flavor properties } & \multicolumn{5}{|c|}{ Content of substances (\% of the total flavor doze) in beer } \\
\cline { 2 - 6 } & Strong beer & Bitter beer & Aromatic beer & $\begin{array}{c}\text { Regular beer } \\
\text { Beer-based } \\
\text { beverages }\end{array}$ \\
\hline Hop bitterness & 30 & 40 & 14 & 28 & 10 \\
\hline Malty off-flavor & 16 & 16 & 34 & 31 & 30 \\
\hline Sugary-sweet off-flavor & 1 & 1 & 12 & 12 & 27 \\
\hline Fruit off-flavor & 12 & 12 & 12 & 8 & - \\
\hline Sulfur off-flavor & 8 & 8 & 17 & 17 & 13 \\
\hline Winy, alcohol-fusel off-flavor & 30 & 20 & 3 & 3 & - \\
\hline Fat and soap off-flavor & 3 & 3 & & & - \\
\hline
\end{tabular}


Beer supports of certain tastes and flavors are well known. This is usually by-products of yeast fermentation. During fermentation a number of metabolic products are formed, which undergo quantitative and qualitative changes, and partly react with each other (Fig. 2). Along with the main products of fermentation (ethanol and carbon dioxide) a number of by-products are formed glycerol, higher alcohols, volatile and fatty acids, esters, aldehydes and their derivatives, sulfur-containing compounds. All these components are a small share of beer. Nevertheless, all by-products of fermentation can affect the beer flavor, even if their concentrations are below threshold concentrations.

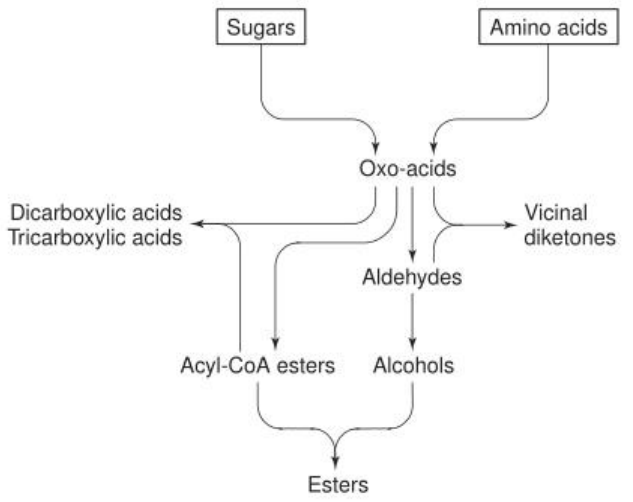

Fig. 2. Relationships between the major classes of yeast-derived beer flavor compounds [10]
Instability of beer flavor characteristics is the problem number one in the world brewing. It is difficult to solve this problem because there are so many substances that are responsible for the stability of taste, and their composition is unstable [11].

With the introduction of new technologies aimed at reducing the duration of fermentation and maturation, learning by-products of fermentation and the factors influencing their formation and removal becomes extremely important. Recently [12] we optimized the main fermentation process of high gravity wort with pentanol and ethyl acetate. However, flavor profile of beer involves other byproducts of fermentation as well.

So the investigations concerning the synthesis of flavor components for improved technology of beer, including HGB-technology are actual and important for the further development of brewing and improving organoleptic characteristics of the beverage.

\section{Experimental}

Saflager W-34/70 yeast, beer hopped wort with the concentration of 14, 16 and $18 \% \mathrm{CP}$ and distillates of young beer were the research objects. Procedures of yeast cultivation, high gravity wort fermentation and determination of by-products content in young beer distillates were described in [12].

Table 2

Characteristics of main flavor substances in beer

\begin{tabular}{|c|c|c|c|c|}
\hline Flavor substances & $\begin{array}{l}\text { Term } \\
\text { according to } \\
\text { EBC }\end{array}$ & Threshold values, $\mathrm{mg} / \mathrm{dm}^{3}$ & $\begin{array}{c}\text { Threshold values } \\
\text { accepted for } \\
\text { calculations, } \mathrm{mg} / \mathrm{dm}^{3}\end{array}$ & Flavor \\
\hline \multicolumn{5}{|c|}{ Higher alcohols } \\
\hline Propyl & 0110 & $800^{\mathrm{a}}, 800^{\mathrm{b}}, 600^{\mathrm{d}},(2-50)^{\mathrm{g}}$ & 600 & \multirow{4}{*}{$\begin{array}{l}\text { Alcoholic, winy, solvent- } \\
\text { like }\end{array}$} \\
\hline Butyl & 0110 & $450^{\mathrm{a}}, 200^{\mathrm{e}}$ & 200 & \\
\hline Isobutyl & 0110 & $\begin{array}{l}200^{\mathrm{a}}, 200^{\mathrm{b}},(10,200)^{\mathrm{c}}, \\
\quad(80-100)^{\mathrm{d}},(5-20)^{\mathrm{g}},\end{array}$ & 200 & \\
\hline $\begin{array}{l}\text { Isoamyl: } \\
\text { 2-methyl-butanol } \\
\text { 3-methyl-butanol }\end{array}$ & 0112 & $\begin{array}{l}70^{\mathrm{b}},(30-70)^{\mathrm{dg}} \\
65^{\mathrm{a}},(10,65)^{\mathrm{cg}} \\
70^{\mathrm{a}},(30,70)^{\mathrm{cg}}\end{array}$ & $\begin{array}{l}65 \\
70\end{array}$ & \\
\hline \multicolumn{5}{|c|}{ Esters } \\
\hline Isoamyl acetate & 0131 & $\begin{array}{c}(0.5-1.7)^{\mathrm{a}}, 1.2^{\mathrm{b}}, \\
(1-1.6)^{\mathrm{c}},(1.6-5)^{\mathrm{e}}, 1.4^{\mathrm{g}}\end{array}$ & 1.6 & $\begin{array}{l}\text { Estery, banana, pear fruit } \\
\text { drops }\end{array}$ \\
\hline Ethyl acetate & 0133 & $\begin{array}{c}(20-40)^{\mathrm{a}}, 30^{\mathrm{b}} \\
(25-30)^{\mathrm{cg}}\end{array}$ & 30 & Fruity, solvent-like \\
\hline \multicolumn{5}{|c|}{ Carbonyl compounds } \\
\hline Acetaldehyde & 0150 & $\begin{array}{l}(10-20)^{\mathrm{a}},(5-20)^{\mathrm{d}}, \\
(20-25)^{\mathrm{e}},(5-15)^{\mathrm{g}}\end{array}$ & 20 & $\begin{array}{c}\text { Green and broken apples, } \\
\text { apple peel }\end{array}$ \\
\hline Diacetyl & 0620 & $\begin{array}{c}(0.1-0.15)^{\mathrm{acg}} \\
(0.01-0.4)^{\mathrm{d}},(0.1-0.12)^{\mathrm{e}}\end{array}$ & 0.1 & Oily, honey \\
\hline \multicolumn{5}{|c|}{ Acids } \\
\hline Acetic acid & 0910 & $60-120^{\mathrm{a}}, 200^{\mathrm{b}}, 130^{\mathrm{d}}$ & 120 & Acetic \\
\hline
\end{tabular}

Notes: ${ }^{\mathrm{a}}-$ M. Meilgaard [5], ${ }^{\mathrm{b}}-$ Y. Tan [13], ${ }^{\mathrm{c}}-$ H. Miedaner [14], ${ }^{\mathrm{d}}-\mathrm{T}$. Barnes [15], ${ }^{\mathrm{e}}-$ L. Narziß [16], ${ }^{\mathrm{g}}-$ B. Hivrych [17]. 
Flavor profile of beer is evaluated by flavor units (FU), and calculated according to the formula

$$
F U=\frac{C}{T},
$$

where $C$ is the concentration of the substance causing a flavor and $T$ is a sensitivity threshold of human receptors before the appearance of this substance in beer.

Threshold values for flavor substances recommended by the authors [5, 13-17] and taken for the calculations in this study are shown in Table 2.

\section{Results and Discussion}

Flavor profile of beer obtained by HGB technology depends on the wort concentration and fermentation temperature.

At fermentation temperature of $282 \mathrm{~K}$ the dependencies of the content of flavoring and aromatic substances on wort concentration were not linear (Fig. 3). The beer profile obtained from $16 \%$ wort was characterized by the highest content of these substances. Most of them were in the range of values less than the threshold concentrations, i.e. $F U<1$. Only acetaldehyde and diacetyl contents were significantly higher (2.3 and 9 $F U$, respectively). However, during after-fermentation and maturation of young beer the concentrations of these substances will decrease as a result of their recovery. Thus aroma and taste of green, mint, broken apples (term 0150) and oily (term 0620) will disappear.

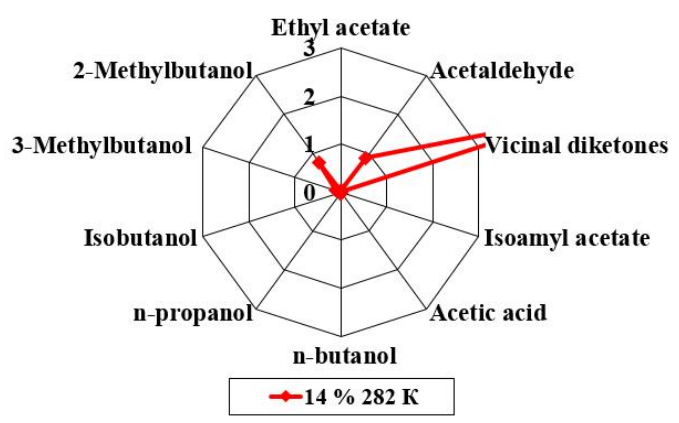

At $287 \mathrm{~K}$ the increase in wort concentration leads to the decrease in acetaldehyde and isoamyl acetate contents (Fig. 4). However, the concentrations of ethyl acetate and 2-methyl butanol increase. Therefore flavor profile of beer is characterized by fruity, solvent-like aroma and taste (term 0133), as well as taste, aroma and burning of white wine, isoamyl alcohol (term 0112).

The increase in wort concentration from 14 to $18 \%$ at $292 \mathrm{~K}$ causes the increase of 3-methyl-butanol and 2methyl-butanol contents (Fig. 5). As a result, the beer will have taste, aroma and burning of white wine, isoamyl alcohol (term 0112).

Thus, cold fermentation at $282 \mathrm{~K}$ better influences the beer quality - the content of substances forming the bouquet of the resulting beer is below the sensitivity threshold. The reason is that the metabolism reactions are slower and not so deep. But at this temperature yeast fermentation activity is low [18] and the main fermentation stage of high gravity wort is longer than that of the traditional technology, that is economically feasible [19].

Formerly warm fermentation was mainly applied for the preparation of dark beer. Nowadays, in order to intensify the processes light beer is also prepared according to warm mode. Higher temperatures generally promote intensification of fermentation [18]. However, at ultrahigh temperatures, $292 \mathrm{~K}$ in particular, the beer with inharmonious flavor is produced, because the content of individual flavoring compounds, including acetaldehyde, ethyl acetate and 2-methyl butanol exceeds the threshold by $2-4$ times (Fig. 5).

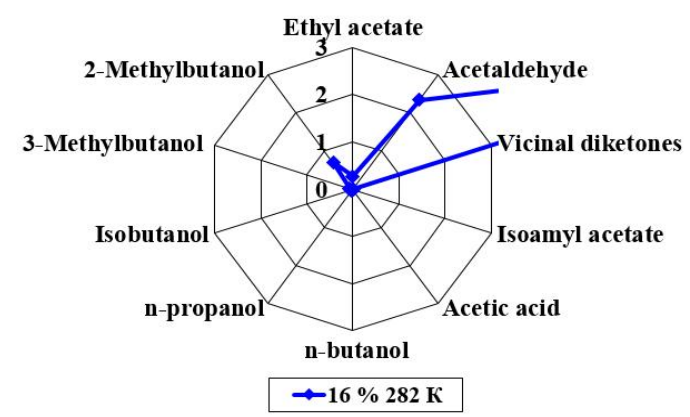

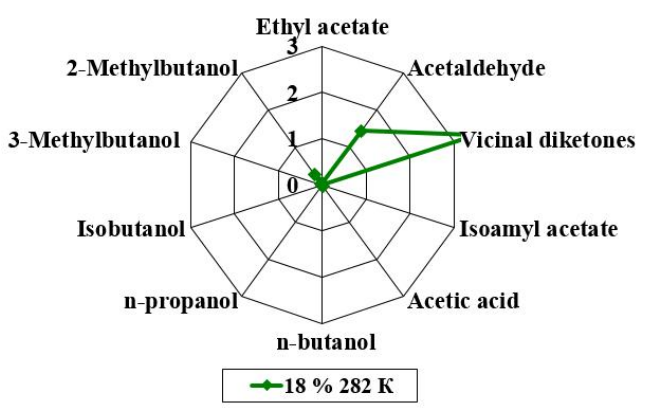

Fig. 3. Flavor profile of young beer obtained at fermentation temperature of $282 \mathrm{~K}$ 

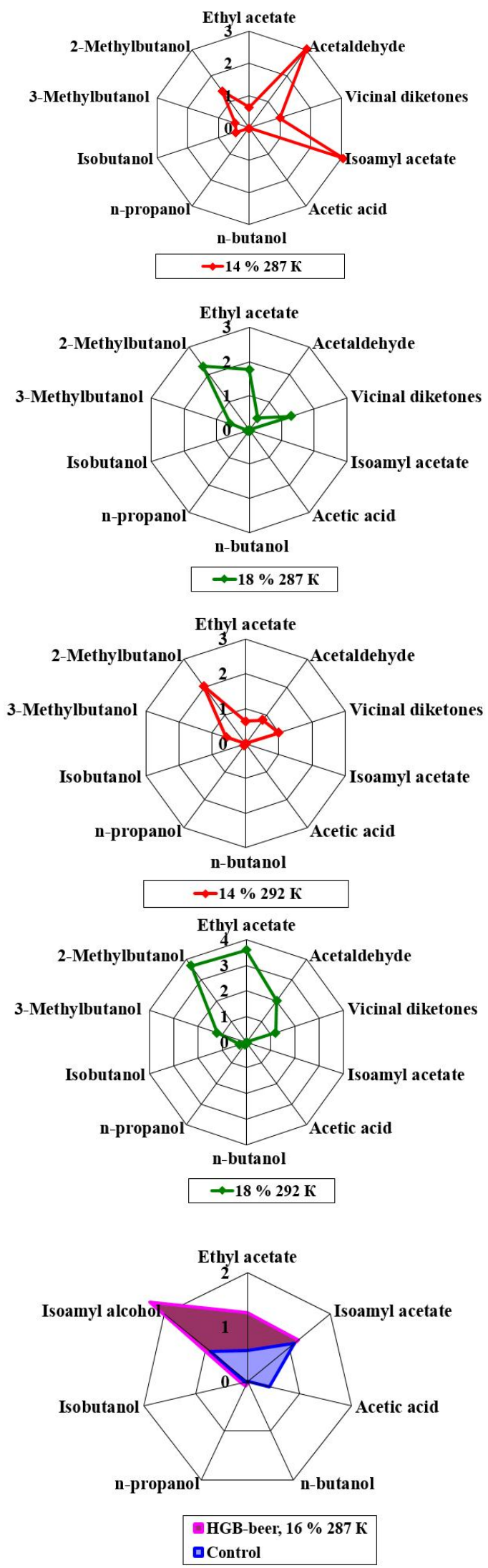

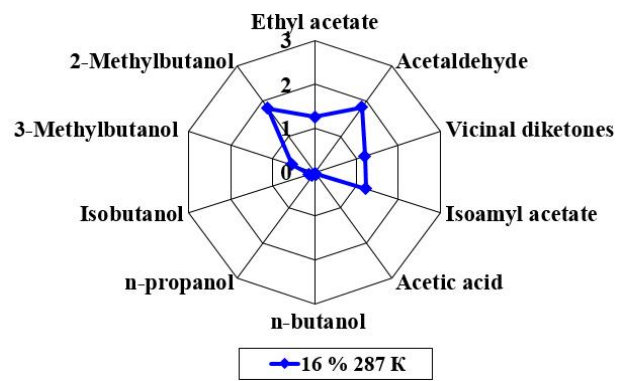

Fig. 4. Flavor profile of young beer obtained at fermentation temperature of $287 \mathrm{~K}$

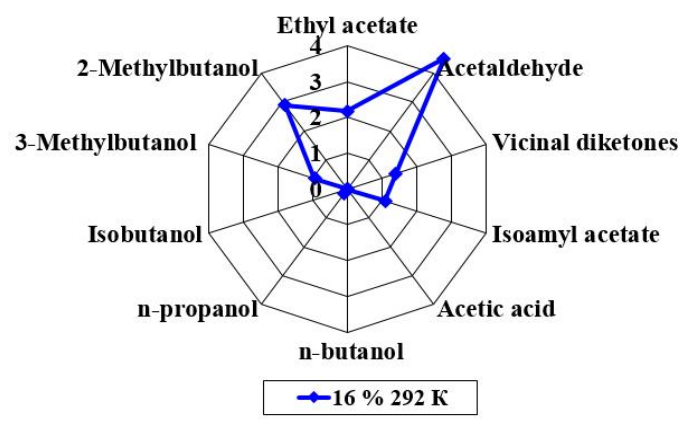

Fig. 5. Flavor profile of young beer obtained at fermentation temperature of $292 \mathrm{~K}$

Fig. 6. Flavor profile of beer obtained by HGB technology compared with traditional technology 
Young beer with good flavor profile was obtained from $16 \%$ wort at $287 \mathrm{~K}$ according to warm mode. The content of isoamyl acetate, ethyl acetate and 2-methyl butanol twice exceeds the threshold, that is typical for the second group of the main flavoring components of the regular beer.

In order to predict the changes in flavor profile of beer obtained according to HGB technology compared with that obtained by traditional technology, we created a new profile taking into account the substances that form the bouquet of the finished beer (higher alcohols and esters). The presence of mentioned components at certain concentrations is a prerequisite for obtaining high-quality beer; their quantity is actually unchanged after the main fermentation of wort (Fig. 6). In contrast, the substances that form the bouquet of young beer (diacetyl and aldehydes), create unclean, green, unripe taste and aroma and their high concentrations negatively affect the quality of beer. They are eliminated during the maturation of young beer. The so-called "zero" beer was chosen for control [4]. The profile of beer obtained by HGB technology was built taking into account the dilution factor of 0.2 . The beer was diluted by prepared water at conditioning stage.

After bringing up to the mark, the beer obtained from $16 \%$ wort at $287 \mathrm{~K}$ according to HGB technology was found to be of high quality with good flavor and aroma profile, because the concentrations of basic components in it are below or close to the sensitivity threshold, i.e. less than $1 F U$. Twofold exceeding of threshold by isoamyl alcohols is typical of the second group of the main flavoring components of beer.

\section{Conclusions}

Flavor profiles of beer obtained by fermentation of high gravity wort with concentration of 14,16 and $18 \mathrm{wt} \%$ at the temperatures of 282,287 and $292 \mathrm{~K}$ were calculated using microcomponents content in young beer. The flavor profiles of beer obtained by laboratory HGBtechnology, and beer, brewed according to traditional tehnology, were compared. The beer of high quality with good flavor and aroma profile may be obtained from $16 \%$ wort at $287 \mathrm{~K}$ according to HGB technology after its bringing up to the mark by the prepared water.

\section{References}

[1] Meilgaard M.: J. Inst. Brewing, 2001, 107, 271. https://doi.org/10.1002/j.2050-0416.2001.tb00098.x

[2] Simpson W.: Brewer Int., 2004, 4, 31.

[3] Schmelzle A.: Dissert. TU Berlin, Verlag Dr. Hut, München 2013.

[4] Meilgaard M.: J. Agricult. Food Chem., 1982, 30, 1009. https://doi.org/10.1021/jf00114a002

[5] Meilgaard M., Reid D., Wyborski K.: J. Am. Soc. Brewing Chemist., 1982, 40, 119.

[6] Tretiak L.: Vestnik Orenburg. Gos. Univ., 2012, 137, 222.

[7] Simpson W.: Organolepticheskyi Analiz v Pivovarenii [in:] Bemfort Ch. (Ed.), Novoe v Pivovarenii. Professiya, SanktPeterburg 2007, 468-501.

[8] ISO 5492:1992.Sensory Analysis: Vocabulary. International Organization for Standardization, Geneva.

[9] Tretiak L.: Fundament. Issledovan., 2014, 9, 1951.

[10] Briggs D., Boulton C., Brookes P., Stevens R.: Brewing. Science and Practice. Woodhead Publ., Cambridge 2004.

[11] Miedaner H., Narziss L., Eichhorn P.: Proceedings of the European Brewery Convention Congress. IRL press at Oxford University Press, Oxford 1991, 401.

[12] Kosiv R., Kharandiuk T., Polyuzhyn L. et al.: Chem. Chem. Technol., 2016, 10, 268. https://doi.org/10.23939/chcht10.03.349

[13] Tan Y., Siebert K.: J. Agric. Food Chem., 2004, 52, 3057. https://doi.org/10.1021/jf035149j

[14] Kunze W.: Technology Brewing and Malting. VLB, Berlin 1996.

[15] Barnes T.: The Complete Beer Fault Guide, V. 1.4, 2011-2013.

[16] Narziss L.: Abriss der Bierbrauwerei. Wiley-VCH, Weinheim 2005.

[17] Khivrych B., Rozdobudko B.: Kharchova Nauka i Technol., 2013, 24, 31.

[18] Kharandiuk T., Kosiv R.: Zbirnyk Nauk. Prats Molodykh Uchenykh, Aspirantiv ta Studentiv, Odesa 2015, 157.

[19] Kharandiuk T., Kosiv R., Palyanytsia L., Berezovska N.: 82 Mizhnar. Nauk. Conf. Molodykh Uchenykh, Aspirantiv ta Studentiv. Ukraine, Kyiv 2016, 224.

Received: October 26, 2016 / Revised: December 20, 2016 / Accepted: J anuary 27, 2017

\section{ВПЛИВ ПАРАМЕТРІВ ЗБРОДЖУВАННЯ ВИСОКОГУСТИННОГО СУСЛА НА СМАКОВИЙ ПРОФІЛЬ ПИВА}

Анотація. Досліджено вплив температури головного бродіння в діапазоні 282-292 К високогустинного пивного сусла конщентрацією 14-18 \% сухих речовин на смаковий профіль молодого пива, зумовлений вмістом смако-ароматичних речовин - побічних продуктів бродіння: ацетальдегіду, віцинальних дікетонів, н-пропанолу, н-бутанолу, ізобутанолу, 2-метилбутанолу, 3-метил-бутанолу, етилацетату, ізоамілацетату.

Ключові слова: пиво, смаковий профіль, високогустинне пивоваріння. 